\title{
Materialism, Fashion Involvement, Fashion Innovativeness and Use Innovativeness: Exploring Direct and Indirect Relationships
}

\author{
Vikas Gautam ${ }^{*}$, Vikram Sharma ${ }^{2}$ \\ ${ }^{1}$ New Delhi Institute of Management, New Delhi, India \\ ${ }^{2}$ Department of Marketing, ICFAI Business School, Gurgaon, India \\ Email: *vgautam78@gmail.com
}

How to cite this paper: Gautam, V. and Sharma, V. (2018) Materialism, Fashion Involvement, Fashion Innovativeness and Use Innovativeness: Exploring Direct and Indirect Relationships. Theoretical Economics Letters, 8, 2444-2459.

https://doi.org/10.4236/tel.2018.811158

Received: July 13, 2018

Accepted: August 19, 2018

Published: August 22, 2018

Copyright $\odot 2018$ by authors and Scientific Research Publishing Inc. This work is licensed under the Creative Commons Attribution International License (CC BY 4.0).

http://creativecommons.org/licenses/by/4.0/

\begin{abstract}
The objective of the current study was to examine the direct and indirect impacts of materialism on use innovativeness in case of fashion products among Indian consumers. An empirical study was conducted to test these relationships with 282 respondents comprised of 59 percent males and 41 percent of females. Proposed conceptual study model was tested with the help of higher order structural equation modeling by using IBM AMOS 21.0. We confirmed full mediation of fashion involvement in the relationship between materialism and use innovativeness. Furthermore, our study results found full mediation of fashion innovativeness in the relationship between materialism and use innovativeness. On the other hand, materialism had a direct significant negative impact on use innovativeness in case of fashion products. We strongly recommend to the fashion product marketers to highlight the concept of use innovativeness in the entire marketing mix for better business prospects.
\end{abstract}

\section{Keywords}

Materialism, Fashion Involvement, Fashion Innovativeness, Use

Innovativeness, Confirmatory Factor Analysis, Structural Equation Modeling, Mediation Analysis

\section{Introduction}

Retail environment in the present scenario provides multiple options to the consumers across the globe for collecting information about various products from different sellers. This facility is adding to the shopping convenience and complete freedom in deciding what to purchase, where to purchase, and when to 
purchase etc. The advent of internet has provided an additional retail channel to the customers. Retailers with multi-channel retaining strategies are adding into dimensions of consumer convenience and easy availability. This strategy is adding to the competitive advantage for a retailer. Multi-channel retailers are more successful and generating higher revenues as compared to single-channel retailers [1]. According to indiaretailing.com [2], the retail market of India is expected to reach USD 1576 billion by 2026, growing at a Compound Annual Growth Rate (CAGR) of $10 \%$. It is predicted that the current Indian fashion retail market will grow at a promising CAGR of 9.7 per cent to reach USD 115 billion by 2026 .

In 1990s, the internet broadened the horizon of retailing for customers with the help of making availability of non-physical stores. Moreover, globalization has played a vital in creating interest among consumers about fashion products. According to [3], globalization is bringing changes in societal aspects across countries. In addition, globalization is able to create awareness among consumers across all regions. Fashion products of one country are quite popular among consumers from different countries. The branding has really gone out of geographical boundaries. Now there are multinational brands available in all markets. According to [4], consumers are very much aware about multinational brands of fashion products. In case of individuals, brands are replica of personal image and we all associate ourselves with the brands. In society, desire to purchase specific brands is linked with self-image in societal context of individuals [5].

Consumer researchers have common understanding that values shape consumer behavior and consumption decision is derived out of it. A value that is catching up in India is materialism and it seems to be a very important factor of consumer behavior. Possession of high-end products like big houses, luxury cars, lavish lifestyles, branded clothes and accessories etc. is becoming a trend among Indian consumers. Humongous increase in credit card business and liberal thoughts about personal loans, car loans, home loans etc. are evidence for materialistic consumerism.

According to [6], an individual understands possession of materialistic products as a vehicle to communicate personal status to society. Materialism possibly will, therefore, symbolize a main indicator of a consumer's association with goods and services that consent to the fulfillment of such values and support in depicting adequate illustrations.

During the last few decades, India has witnessed considerable socio-politicaleconomic changes. Indian consumers have developed strong aspirations for fashion products to be at par with global trends. Low income Indian consumers purchase fashion products to satisfy social needs rather individual needs. With this background of huge potential of this market, the important reasons associated with Indian consumers' attitude towards buying fashion products need to be investigated in order to develop the general understanding of the upcoming market and formulate suitable marketing strategies that would augment success 
of the sector. To fill the gap in the consumer behavior literature, this study intends to assess the impact of materialism on fashion product purchase, fashion innovativeness and perceived use innovativeness. The contribution of this study will be twofold, firstly it will contribute to the body of literature for fashion product purchase process in developing country and how materialism impacts purchase and perceived use innovativeness. Secondly, marketers will get insights to anticipate Indian consumers' requirements in terms of fashion products' purchase and use innovativeness. They will be in better position to formulate marketing mix strategies to get better Return on Investments.

The rest of the article is organized as Theoretical Framework followed by Conceptual Model of the Study, Hypotheses Development, Research Methodology, Data Analysis, Findings, Conclusion, Implications, Limitations and Future Scope of Study.

\section{The Review of Literature}

\subsection{Materialism}

Materialism can be related to possessions, social status and happiness of individuals [7]. [8] defined materialism as "The importance a consumer attaches to worldly possessions". It can be understood as a bundle of interrelated traits, attitudes, and values that center on possessions [9]. [10] posited materialism as a value. Moreover, [11] defined materialism as "The importance a person places on possessions and their acquisition as a necessary or desirable form of conduct to reach desired end states, including happiness". According to [12], materialism is "a set of attitudes which regard possessions as symbols of success, where possessions occupy a central part of life, which include holding the belief that more possessions lead to more happiness".

Past research found the materialistic consumers as; self-absorbed, self-gratifying, and purchase only branded goods and services [11] [13] [14]. For materialistic consumers, happiness lies in possessing premium articles. Authors found three aspects of materialism such as; 1) the role of acquisition in happiness, 2) the role of possessions in defining success, 3) acquisition centrality. Possession of visible wealth and product consumption in public are used by materialistic consumers to boost their status [13]. Authors further argued that demand for money-oriented possessions leads to higher degree of materialism, which subsequently create more demand for fashion products. The materialistic consumers show big concerns about their possessions of fashion products and get involved to a large extent with them.

\subsection{Fashion Involvement}

Fashion products focus on increasing self-image of an individual in a social set-up [15]. These are considered as communicator of an individual in social space about his like and dislikes and also about personality and lifestyle. Clothing as a fashion product works as an aid to consumers in social adaptation and 
expression in public [16]. Fashion is defined by [17] as "A form of collective behavior or a wave of social conformity". Individuals put efforts to enhance social self-image by judiciously selecting fashion products.

Fashion orientation defines the lifestyle statement of an individual [18]. [19] argued that materialistic individuals involve actively with products which communicate public meaning. According to [20], fashion product involvement includes 4 types of involvement namely; product, advertisement, purchase involvement and purchase decision involvement. Author found that all these involvement types are covering pre-purchase level to post-purchase level. Consequently there is high level of involvement on the consumer side. Later in 2013, [21] found that more involved consumers search very actively for additional information in order to become opinion leaders and induce product innovativeness.

Involvement is correlated with behavioral patterns of use in terms of volume and frequency [22]. Author further found that in case of products with multi-functionality, volume and frequency are related with involvement and use innovativeness. [23] found positive relationship among involvement, innovativeness and usage variety. Variety seeking behavior of consumers makes them susceptible for broad range of innovativeness [24]. Actually customers try to discover various ways of using fashion products in order to exhibit innovativeness. Hence fashion involvement is anticipated to be related to use innovativeness. According to [25], a more involved consumer makes better decision with full confidence. Moreover, high fashion involved consumer attaches high importance for selecting and purchasing fashionable products in order to get best fit the individual personality.

\subsection{Fashion Innovativeness}

According to [26], fashion innovativeness is defined as "the degree of innovative propensity of individuals that affects the adoption and acceptance of new fashion products and related services". Fashion innovativeness is a basic characteristic of an individual, which is exhibited by actions of readiness towards new as well as uncommon products [27]. [28] identified two predictors of fashion innovativeness such as; trend involvement, clothing involvement. Therefore, fashion involvement is expected to have relationship with fashion innovativeness.

As per the diffusion of innovation theory, innovative consumers adopt the latest fashion trends at the very early stage and express their innovative behavior with the help of many actions in different situations [29]. These early fashion adopters develop innovativeness because of their psychological attributes. [30] developed the use innovativeness model and confirmed the influence of inherent innovativeness on fashion innovativeness as well as on use innovativeness. Hence, there are high chances of interrelationships between fashion innovativeness and use innovativeness. Fashion innovativeness is related with buying behaviors of consumers and use innovativeness comes into picture after a fashion product is bought. There exists a visible sequence between fashion and use in- 
novativeness. Therefore, fashion innovativeness is expected to pave the way to use innovativeness.

\subsection{Use Innovativeness}

According to [31], use innovativeness concept got its origin from the intuitive and progressive use propensity of an individual in order to keep it suitable for future consumption also. Use innovativeness doesn't deal with misuse of product, but it focuses on how innovatively and numerously a product is serving needs of the consumers [32]. Authors further argued that use innovativeness doesn't deal with crises management, but it highlights the enjoyable behavior of users while using the existing products in a very fresh manner. Innovativeness adds a positive impact in case of a consumer groups who use products in a variety of ways [24]. In the literature, it has been argued that in case of fashion products, use innovativeness takes care of variety in usage, whereas in case of consumable products, it deals with creative consumption. Creativity is understood in the literature as focusing on functional value of the product and honest consumption practice. Creativity in case of fashion products deals with using different fashion items and accessories in such a manner that it conveys style quotient and at the same time it maintains variety. Therefore, a high level of use innovativeness is also likely to persuade the increased use of available products in multiple ways and manners (Figure 1).

\subsection{Hypotheses of the Study}

$\mathrm{H}_{1}$ : Materialism is positively related to Fashion Involvement

$\mathrm{H}_{2}$ : Materialism is positively related to Fashion Innovativeness

$\mathrm{H}_{3}$ : Materialism is negatively related to Use Innovativeness

$\mathrm{H}_{4}$ : Fashion Involvement is positively related to Use Innovativeness

$\mathrm{H}_{5}$ : Fashion Innovativeness is positively related to Use Innovativeness

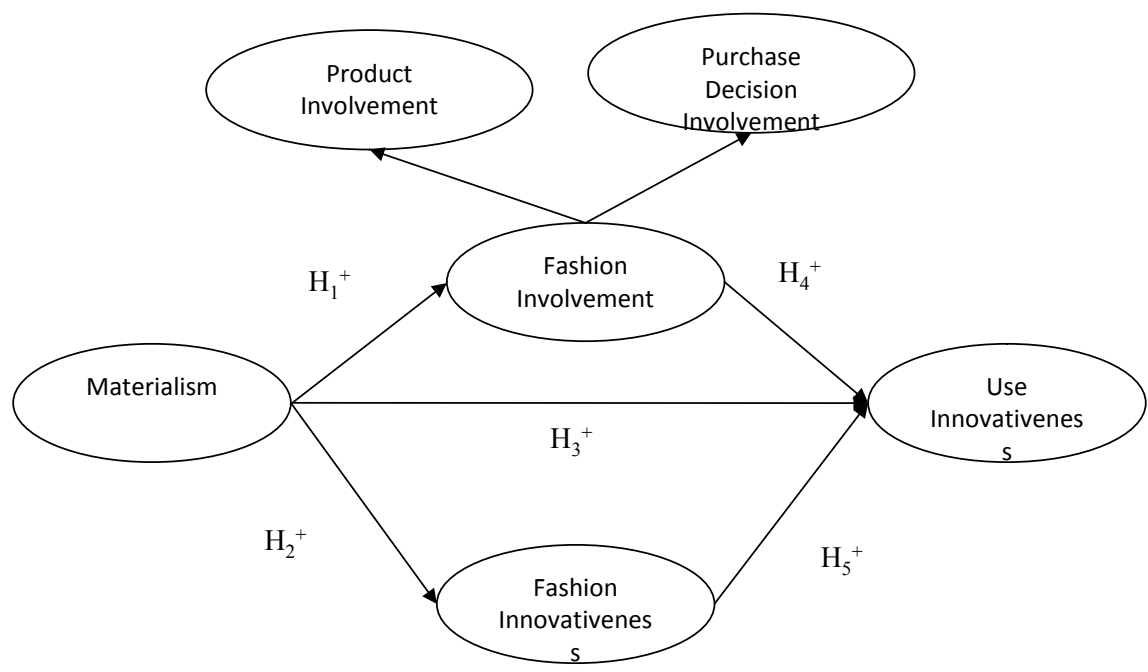

Figure 1. Conceptual study model. 


\subsection{Research Methodology}

In order to investigate the proposed relationships among study constructs such as; materialism, fashion involvement (product and purchase decision involvement), fashion innovativeness, use innovativeness, primary data were collected by using field survey method with the help of a research instrument (structured questionnaire with close-ended questions). The major focus of the indicators or statements used in questionnaire was to understand perception of consumers about materialism, fashion involvement, fashion and use innovativeness.

\subsection{Sampling Design and Data Collection}

The population under study included consumers residing in National Capital Region (NCR) of India. NCR consists of Delhi (Capital of India), Gurugram, NOIDA, Faridabad, Ghaziabad, Meerut. This region attracts people from all over India. We can witness people from all corners of India staying here at NCR. Survey administration in such area provided us an added advantage as our sample got diverse set of respondents, representing various parts of India. We used purposive sampling method to collect primary data for the study.

We have collected 303 duly filled questionnaires from the target respondents. After removal of incomplete questionnaires (21), wherein too much amounts of important data were missing, we were left with final 282 questionnaires. To assess the direct and indirect relationships among the study constructs, namely; materialism, fashion involvement (product and purchase decision involvement), fashion innovativeness, use innovativeness, higher order Structural Equation Modeling (SEM) with IBM AMOS 21.0 (Covariance based SEM) with Maximum Likelihood Estimation (MLE) was used. This multivariate statistical analysis technique provides robust results in case the sample size of study is appropriate. As a rule of Thumb, in case of Structural Equation Modeling (SEM), any number above 200 (critical sample size) is understood to give adequate statistical power for analysis of the study data [33] [34]. In this study, a final sample size of 282 (after removal of incomplete questionnaires) is found suitable for testing study model and proposed hypotheses.

\subsection{Research Instrument}

To measure study constructs, we have adopted scales from Materialism [11], Fashion Product Involvement [35], Fashion Product Purchase Involvement [36], Fashion Innovativeness [37], Use Innovativeness [38]. All the study variables were measured on seven point Likert's scale $(1=$ Strongly Disagree, 2 = Disagree, 3 = Somewhat Disagree, $4=$ Neither Disagree Nor Agree, $5=$ Somewhat Agree, $6=$ Agree, $7=$ Strongly Agree). In addition, the research instrument included six socio-demographical variables such as; age, gender, marital status, educational qualification, employment status, monthly household income in INR. These all socio-demographical variables were measured on nominal scale. 


\subsection{Data Analysis}

After collection and preparation of study data, we analyzed it to meet the objectives of the study and draw meaning insights. The analysis includes general sample description, Cronbach's alpha to assess reliability of the research instrument, Confirmatory Factor Analysis (CFA) to test the model fit, Structural Equation Modeling (SEM) using IBM AMOS 21.0 to estimate structural model and hypotheses of the study.

It can be seen from Table 1 that majority of the respondents were less than 25 years of age followed by age group of 26 to 35 years. Sample had 58.90 percent of males and 41.10 percent females. Our sample had more number of unmarried respondents as compared to married ones. More than fifty percent of the respondents were either graduate or post-graduate.

In our survey of respondents, it was found that the respondents are from different income backgrounds; a major part of them belong to monthly household income of more than 71,000 INR.

Table 1. General sample description.

\begin{tabular}{|c|c|c|c|c|}
\hline S.N. & Variable & Levels & Number & Percentage \\
\hline \multirow{5}{*}{1} & \multirow{5}{*}{ Age (in Years) } & Below 25 & 195 & 69.10 \\
\hline & & $26-35$ & 48 & 17.00 \\
\hline & & $36-45$ & 28 & 9.90 \\
\hline & & $46-55$ & 6 & 2.10 \\
\hline & & Above 55 & 5 & 1.80 \\
\hline \multirow{2}{*}{2} & \multirow{2}{*}{ Gender } & Female & 116 & 41.10 \\
\hline & & Male & 166 & 58.90 \\
\hline \multirow{2}{*}{3} & \multirow{2}{*}{ Marital Status } & Unmarried & 227 & 80.50 \\
\hline & & Married & 55 & 19.50 \\
\hline \multirow{3}{*}{4} & \multirow{3}{*}{ Educational Qualification } & Intermediate & 133 & 47.20 \\
\hline & & Graduate & 133 & 47.20 \\
\hline & & Post Graduate & 16 & 5.60 \\
\hline \multirow{5}{*}{5} & & Salaried & 84 & 29.80 \\
\hline & & Student & 184 & 65.20 \\
\hline & Employment Status & Business & 184 & 0.70 \\
\hline & & Professional & 7 & 2.50 \\
\hline & & Others & 5 & 1.80 \\
\hline \multirow{5}{*}{6} & \multirow{5}{*}{ Monthly Household Income (In Rs.) } & Below 50,000 & 11 & 3.90 \\
\hline & & $51,000-70,000$ & 43 & 15.20 \\
\hline & & $71,000-90,000$ & 56 & 19.90 \\
\hline & & $91,000-110,000$ & 63 & 22.30 \\
\hline & & Above 110,000 & 109 & 38.70 \\
\hline
\end{tabular}

Source: Author compilation. 


\subsection{Reliability Analysis}

According to [39], in order to pass the test of reliability for measurement scales, the reliability coefficient (Cronbach's alpha) should be greater than 0.70 . It can be seen from Table 2 that all Cronbach's alpha values range from 0.763 to 0.972 . Hence the measurement scales of the current study pass the test of reliability (Figure 2).

This study had one second order construct namely fashion involvement and three other first order constructs. The Confirmatory Factor Analysis (CFA) model with these 4 constructs had a total of 110 distinct parameters and 630 distinct sample moments. During model estimation, a minimum was achieved with Chi-Square value $904.014(\mathrm{DF}=520, \mathrm{p}<0.000)$. All the parameters of the given study were practicable and standard errors in acceptable limits. Statistical significance of parameter estimates was established as test-statistic (t-value) in each case was greater than threshold limit of 2.58 (5 percent significance level).

It can be seen from Table 3 that all absolute fit indices and comparative fit indices are meeting their threshold levels [41] [42]. Hence measurement model of the study is confirmed.

\subsection{Convergent and Discriminant Validity}

In order to generalize sample results for entire population under study, it is very important to pass the test of construct validity. According to [40], construct validity can be tested through convergent and Discriminant validity. Construct validity can be achieved if Composite Reliability (CR) of all study constructs reaches or crosses the threshold of 0.70 and Average Variance Explained (AVE) should be a minimum of 0.50 .

In case of Discriminant validity, the AVE should be greater than Maximum Shared Variance (MSV) or AVE should be greater than Average Shared Variance (ASV) or ASV should be greater than MSV, and the square root of AVE should be greater than correlation among the constructs under consideration [40] [43].

It is quite evident from Table 4 that Composite Reliability (CR) and Average Variance Explained (AVE) in case of all 4 study constructs met the desired criteria.

Table 2. Reliability analysis results.

\begin{tabular}{cccc}
\hline S.N. & Name of Construct & Number of Items & Cronbach's Alpha \\
\hline 1 & Materialism & 9 & 0.820 \\
2 & Fashion Product Involvement & 13 & 0.969 \\
3 & Fashion Product Purchase Involvement & 8 & 0.927 \\
4 & Fashion Involvement & 21 & 0.972 \\
5 & Fashion Innovativeness & 3 & 0.763 \\
6 & Use Fashion Product Involvement & 3 & 0.804 \\
\hline
\end{tabular}

Source: Author compilation. 


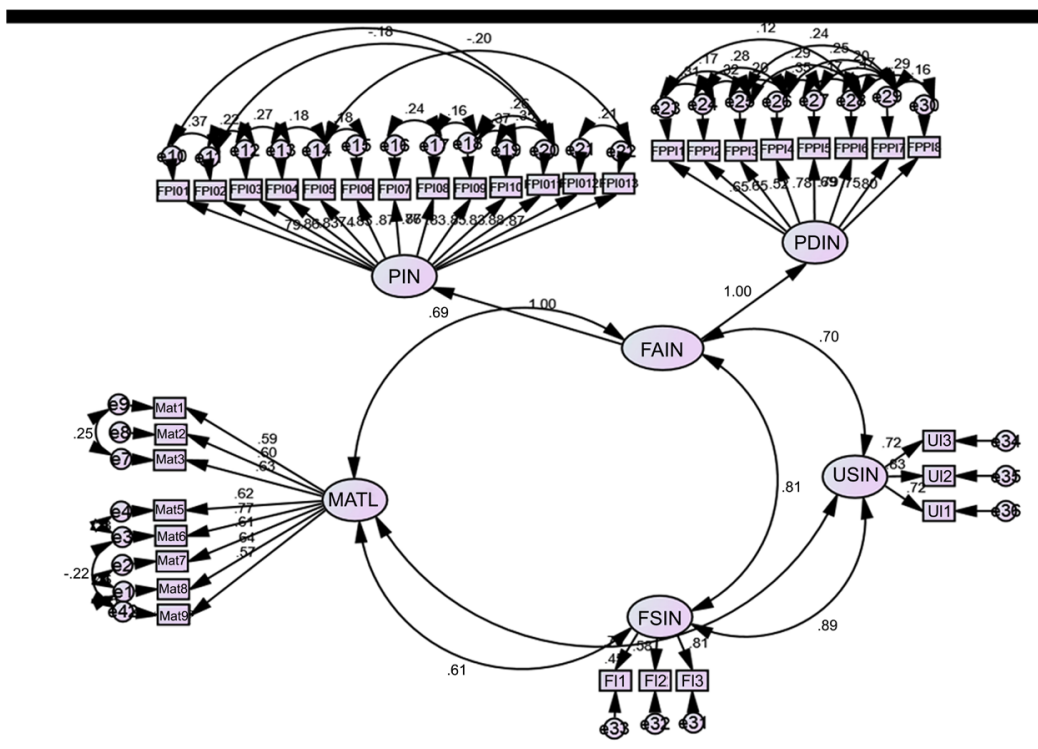

Figure 2. Confirmatory factor analysis.

Table 3. Model fit indices.

\begin{tabular}{|c|c|c|c|}
\hline S. N.* & Goodness of Fit Index & Value $^{*}$ & Acceptable Threshold Value \\
\hline 1 & CMIN & 904.014 & - \\
\hline 2 & Df (Degrees of Freedom ) & 520 & - \\
\hline 3 & CMIN/DF & 1.738 & good if $<3$ \\
\hline 4 & GFI (Goodness of Fit Index) & 0.842 & $\begin{array}{c}\text { Range } 0 \text { - } 1 \text {, good if more } \\
\text { towards } 1\end{array}$ \\
\hline 5 & IFI (Incremental Fit Index) & 0.952 & good if $\geq 0.90$ \\
\hline 6 & TLI (Tucker-Lewis Index) & 0.944 & good if $\geq 0.90$ \\
\hline 7 & CFI (Comparative fit Index) & 0.951 & good if $\geq 0.90$ \\
\hline 8 & $\begin{array}{l}\text { RMSEA (Root Mean Square } \\
\text { Error of Approximation) }\end{array}$ & 0.051 & good if $<0.08$ \\
\hline 9 & P Close & 0.349 & good if close to or equal to 1 \\
\hline 10 & $\begin{array}{l}\text { ECVI (Expected Cross } \\
\text { Validation Index) }\end{array}$ & $\begin{array}{c}\text { Default Model }=4.000 \\
\text { ECVI value for Saturated } \\
\text { Model }=4.484 \\
\text { ECVI value for } \\
\text { Independence Model }= \\
30.418\end{array}$ & $\begin{array}{l}\text { Default model should have } \\
\text { least ECVI value }\end{array}$ \\
\hline
\end{tabular}

*Source: Author compilation; ${ }^{*}$ source: [40].

Table 4. Convergent and discriminant validity results.

\begin{tabular}{ccccccccc}
\hline & CR & AVE & MSV & ASV & USIN & MATL & FSIN & FAIN \\
\hline USIN & 0.801 & 0.574 & 0.431 & 0.489 & $\mathbf{0 . 7 5 8}$ & & & \\
MATL & 0.840 & 0.599 & 0.349 & 0.480 & 0.445 & $\mathbf{0 . 7 7 4}$ & & \\
FSIN & 0.756 & 0.513 & 0.436 & 0.505 & 0.385 & 0.408 & $\mathbf{0 . 7 1 6}$ & \\
FAIN & 1.000 & 1.000 & 0.463 & 0.543 & 0.497 & 0.393 & 0.414 & $\mathbf{1 . 0 0 0}$ \\
\hline
\end{tabular}

Source: Author compilation. 
Hence convergent validity is established. Moreover, AVE is greater than Maximum Shared Variance (MSV) or AVE is greater than Average Shared Variance (ASV) or ASV is greater than MSV, and the square root of AVE is greater than correlation among the study constructs. Therefore, following the criteria recommended by [42] [43], it can be concluded that Discriminant validity of the measurement scale is established.

\subsection{Structural Equation Modeling Results}

It is evident from Table 5 that the direct impact of materialism on use innovativeness is negative and significant $(\beta=-0.427, \mathrm{p}=0.007)$. Further, materialism positively impacts fashion involvement $(\beta=0.783, \mathrm{p}<0.000)$. We also found positive and significant impact of materialism on fashion innovativeness $(\beta=$ $0.744, \mathrm{p}<0.000)$. Study results confirmed significant positive impact of fashion involvement on use innovativeness $(\beta=0.297, \mathrm{p}<0.000)$. Additionally, we found significant positive impact of fashion innovativeness on use innovativeness $(\beta=0.9781, \mathrm{p}<0.000)$.

[44] suggested the steps to conduct mediation analysis by using Structural Equation Modeling (SEM) with IBM AMOS.

The following 4 steps were followed:

$1^{\text {st }}$ Step: Firstly, path coefficient with p-value was calculated for direct relationship between Materialism (Predictor Variable) and Use Innovativeness (Dependent Variable) was calculated

$2^{\text {nd }}$ Step: Secondly, path coefficient with p-value was calculated for direct relationship between Materialism (Predictor Variable) and Use Innovativeness (Dependent Variable) with inclusion of fashion involvement as mediating variable.

$3^{\text {rd }}$ Step: Thirdly, path coefficient with $\mathrm{p}$-value for indirect relationship was checked with the help of bootstrapping (standardized indirect path coefficient with confidence interval) to decide about no, partial or full mediation.

$4^{\text {th }}$ Step: The same above 3 steps were followed for second mediating variable.

It can be seen from Table 6 that fashion involvement fully mediates ( $\beta=$ $0.158, p=0.010)$ the path between materialism and use innovativeness. Further, it is also evident that fashion innovativeness mediates fully $(\beta=0.589, \mathrm{p}=0.010)$ the path between materialism and use innovativeness.

It can be seen from Table 7 that all study hypotheses were supported at 5 percent level of significance $\left(\mathrm{H}_{1}: \beta=0.783, \mathrm{p}=0.000 ; \mathrm{H}_{2}: \beta=0.744, \mathrm{p}=0.000 ; \mathrm{H}_{3}: \beta\right.$ $\left.=-0.427, \mathrm{p}=0.007 ; \mathrm{H}_{4}: \beta=0.297, \mathrm{p}=0.000 ; \mathrm{H}_{5}: \beta=0.781, \mathrm{p}=0.000\right)$.

\section{Conclusion and Implications of the Study}

The results of the current study revealed the direct and indirect relationships of materialism with use innovativeness. Specifically, the mediating role of fashion product involvement in explaining use innovativeness is strongly supported. The hypothesis test clearly indicated that materialistic consumers do not go for use 
Table 5. Path coefficients.

\begin{tabular}{cccccc}
\hline Relationship & $\begin{array}{c}\text { Unstandardized Path Standardized Path } \\
\text { Coefficient }\end{array}$ & C. R. & p-value & R-Square \\
\hline USIN <--- MATL & -0.421 & -0.427 & -2.701 & 0.007 & \\
FAIN <--- MATL & 0.990 & 0.783 & 9.057 & 0.000 & \\
FSIN <--- MATL & 0.881 & 0.744 & 8.530 & 0.000 & 0.78 \\
USIN <--- FAIN & 0.381 & 0.297 & 3.894 & 0.000 & \\
USIN <--- FSIN & 0.940 & 0.781 & 6.609 & 0.000 & \\
\hline
\end{tabular}

Source: Author Compilation.

Table 6. Path coefficients.

\begin{tabular}{cccc}
\hline Relationship & $\begin{array}{c}\text { Direct without } \\
\text { Mediator }\end{array}$ & Direct with Mediator & Indirect Path \\
\hline USIN <--- MATL & $0.437(0.000)$ & FAIN & $0.158(0.010)$ \\
& & $0.076(0.383)$ & Full Mediation \\
USIN <--- MATL & $0.437(0.000)$ & FSIN & $0.589(0.010)$ \\
& & $-0.147(0.075)$ & Full Mediation \\
\hline
\end{tabular}

Source: Author Compilation.

Table 7. Summary of hypotheses of the study.

\begin{tabular}{ccccc}
\hline Path & Hypothesis & Path Coefficient & p-value & Result \\
\hline FAIN <--- MATL & $\mathrm{H}_{1}$ & 0.783 & 0.000 & Supported \\
FSIN <--- MATL & $\mathrm{H}_{2}$ & 0.744 & 0.000 & Supported \\
USIN <--- MATL & $\mathrm{H}_{3}$ & -0.427 & 0.007 & Supported \\
USIN <--- FAIN & $\mathrm{H}_{4}$ & 0.297 & 0.000 & Supported \\
USIN <--- FSIN & $\mathrm{H}_{5}$ & 0.781 & 0.000 & Supported \\
\hline
\end{tabular}

Source: Author Compilation.

innovativeness. It is obvious that use innovators deal with the products and accessories in wide variety of ways. Our study results confirmed significant positive impacts of fashion involvement and fashion innovativeness on use innovativeness. Interestingly we found full mediation of fashion involvement in the relationship of materialism and use innovativeness. Moreover, fashion innovativeness also confirmed full mediating impact on the relationship of materialism and use innovativeness.

According to [45], innovativeness has a significant impact on how consumers purchase new products and brands. Earlier in 1992, [46] confirmed differences among high and less innovative consumers. Authors posited that more innovative consumers differentiate themselves from low innovative consumers by purchasing products more frequently and larger spending. Therefore, it can be concluded that materialistic consumers are more fashion involved and exhibit fashion innovativeness, but show inverse relationship with use innovativeness. 
Further, we found significant positive impact of fashion involvement on use innovativeness. This indicates that consumers who are involved with reference to product and purchase decision express innovativeness in the use of the fashion products. On the other hand, our study model confirmed significant positive impact of fashion innovativeness on use innovativeness. This tells that fashion innovators devise various ways of innovativeness while using the fashion products. Similarly our model found positive significant impacts of materialism on fashion involvement and fashion innovativeness.

Another very interesting relationship we found in our model was full mediating impacts of fashion involvement and fashion innovativeness in the relationships between materialism and use innovativeness. This finding in our model is vital especially when path from materialism to use innovativeness through fashion involvement and fashion innovativeness became insignificant. This highlights a very interesting aspect of consumer psychology that materialistic consumers exhibit use innovativeness in case of involvement and innovativeness in fashion products.

Based on findings of our research, a few academic implications can be proposed. In consumer research literature, majority of the researchers focused on purchase intentions and purchase decision. The post-purchase phase has not been highlighted to that extent. These findings make significant academic contribution in the area of post-purchase behavior of consumers. Taking cue from this research, scholars can think of using some new variables in their research works to get valuable insights about consumer characteristics. Other aspect our study highlighted that materialistic consumers exhibit different use innovativeness in case of fashion products with reference to involvement and purchase decision. This research contributes to the empirical research on the theme of role of materialism on use innovativeness in case of fashion products directly and indirectly through fashion involvement and innovativeness.

\section{Limitations and Future Scope of the Study}

Some boundaries may be appropriate when we generalize the results of this research due to the cross-sectional data collected from one geographical area. Future studies with broader samples with diverse demography and geography must be conducted to widen the generalizability and validation of the model with some additional constructs in order to better understand the purchase intentions of the consumers. Life cycle of the product has shortened in the current market conditions due to swift changes in tastes and preferences of consumers. This trend has convinced consumers to restrict usage of a fashion product for a short duration. As a result, innovativeness in use of different fashion products has come out a big research area for the scholars in the area of consumer psychology. Short life cycle of products also contributes towards environmental and health hazards due to wastage creation during new product production process. Hence product involvement and also product purchase-process involvement are 
of vital importance for further research in order to have sustainable environment.

\section{Summary Statement of Contribution}

This study confirmed significant positive impacts of fashion involvement and fashion innovativeness on use innovativeness. Further, we found full mediation of fashion involvement and fashion innovativeness among the proposed relationships in the study model. This finding in our model is vital especially when path from materialism to use innovativeness through fashion involvement and fashion innovativeness became insignificant. This highlights a very interesting aspect of consumer psychology that materialistic consumers exhibit use innovativeness in case of involvement and innovativeness in fashion products.

\section{Conflicts of Interest}

The authors declare no conflicts of interest regarding the publication of this paper.

\section{References}

[1] DoubleClick (2004) Retail Details: Best Practices in MultiChannel Integration Research Report, DoubleClick, New York (March).

[2] https://www.indiaretailing.com/2017/10/15/fashion/indian-fashion-apparel-market2016-beyond/

[3] De Mooij, M. (2013) Global Marketing and Advertising: Understanding Cultural Paradoxes. Sage Publications.

[4] Kumar, A., Lee, H.J. and Kim, Y.K. (2009) Indian Consumers' Purchase intention toward a United States versus Local Brand. Journal of Business Research, 62, 521-527. https://doi.org/10.1016/j.jbusres.2008.06.018

[5] Belk, R.W. (1988) Possessions and the Extended Self. Journal of Consumer Research, 15, 139-168. https://doi.org/10.1086/209154

[6] Douglas, M. and Isherwood, B. (1979) The World of Goods. Basic, New York.

[7] Ward, S. and Wackman, D. (1971) Family and Media Influences on Adolescent Consumer Learning. American Behavioral Scientist, 14, 415-427. https://doi.org/10.1177/000276427101400315

[8] Belk, R.W. (1984) Three Scales to Measure Constructs Related to Materialism: Reliability, Validity, and Relationships to Measures of Happiness. ACR North American Advances.

[9] Belk, R.W. (1985) Materialism: Trait Aspects of Living in the Material World. Journal of Consumer Research, 12, 265-280. https://doi.org/10.1086/208515

[10] Founier, S. and Richins, M.L. (1991) Some Theoretical and Popular Notions Concerning Materialism. Journal of Social Behavior and Personality, 6, 403.

[11] Richins, M.L. and Dawson, S. (1992) A Consumer Values Orientation for Materialism and Its Measurement: Scale Development and Validation. Journal of consumer research, 19, 303-316. https://doi.org/10.1086/209304

[12] Chan, K. and Prendergast, G. (2007) Materialism and Social Comparison among Adolescents. Social Behavior and Personality: An International Journal, 35, 
213-228. https://doi.org/10.2224/sbp.2007.35.2.213

[13] Liao, Y.P. and Wang, S.S. (2009) A Secure Dynamic ID Based Remote User Authentication Scheme for Multi-Server Environment. Computer Standards \& Interfaces, 31, 24-29. https://doi.org/10.1016/j.csi.2007.10.007

[14] Moschis, G.P. and Churchill Jr., G.A. (1978) Consumer Socialization: A Theoretical and Empirical Analysis. Journal of Marketing Research, 599-609. https://doi.org/10.2307/3150629

[15] Dubois, B. and Duquesne, P. (1993) The Market for Luxury Goods: Income versus Culture. European Journal of Marketing, 27, 35-44. https://doi.org/10.1108/03090569310024530

[16] Creekmore, A.M. (1974) Clothing Related to Body Satisfaction and Perceived Peer Self (Research Report No. 239). Michigan State University Agricultural Experiment Station, East Lansing.

[17] Solomon, M.R. and Rabolt, N.J. (2004) Consumer Behavior: In Fashion. Prentice Hall, Upper Saddle River.

[18] Huddleston, P., Ford, I. and Bickle, M.C. (1993) Demographic and Lifestyle Characteristics as Predictors of Fashion Opinion Leadership among Mature Consumers. Clothing and Textiles Research Journal, 11, 26-31. https://doi.org/10.1177/0887302X9301100404

[19] Browne, B.A. and Kaldenberg, D.O. (1997) Conceptualizing Self-Monitoring: Links to Materialism and Product Involvement. Journal of Consumer Marketing, 14, 31-44. https://doi.org/10.1108/07363769710155848

[20] O’Cass, A. (2000) An Assessment of Consumers' Product, Purchase Decision, Advertising and Consumption Involvement in Fashion Clothing. Journal of Economic Psychology, 21, 545-576. https://doi.org/10.1016/S0167-4870(00)00018-0

[21] Naderi, I. (2013) Beyond the Fad: A Critical Review of Consumer Fashion Involvement. International Journal of Consumer Studies, 37, 84-104. https://doi.org/10.1111/j.1470-6431.2011.01041.x

[22] Stone, G.P. (1954) City Shoppers and Urban Identification: Observations on the Social Psychology of City Life. American Journal of Sociology, 60, 36-45. https://doi.org/10.1086/221483

[23] Ram, S. and Jung, H.S. (1989) The Link between Involvement, Use Innovativeness and Product Usage. Advances in Consumer Research, 16, 160-166.

[24] Shih, C.F. and Venkatesh, A. (2004) Beyond Adoption: Development and Application of a Use-Diffusion Model. Journal of marketing, 68, 59-72. https://doi.org/10.1509/jmkg.68.1.59.24029

[25] Vieira Afonso, V. (2009) An Extended Theoretical Model of Fashion Clothing Involvement. Journal of Fashion Marketing and Management: An International Journal, 13, 179-200. https://doi.org/10.1108/13612020910957707

[26] Kim, J.B. and Rhee, D. (2001) The Relationship between Psychic Distance and Foreign Direct Investment Decisions: A Korean Study. International Journal of Management, 18, 286-286.

[27] Jun, D.G. and Rhee, E.Y. (2009) The Effects of Fashion Innovativeness and Style-Innovation Attributes of Fashion Adoption. Journal of the Korean Society of Clothing and Textiles, 33, 1564-1574. https://doi.org/10.5850/JKSCT.2009.33.10.1564

[28] Jun, D.G., Choo, H.J. and Kim, H.S. (2010) A Study on the Clothing Involvement, Fashion Innovativeness, Impulsive Buying, and Brand Loyalty of Male University 
Students. Journal of the Korean Society of Clothing and Textiles, 34, 424-436. https://doi.org/10.5850/JKSCT.2010.34.3.424

[29] Rhee, E.Y. (1991) Fashion Marketing. 2nd Edition, Kyomunsa, Gyeonggi.

[30] Ridgway, N.M. and Price, L.L. (1994) Exploration in Product Usage: A Model of Use Innovativeness. Psychology \& Marketing, 11, 69-84. https://doi.org/10.1002/mar.4220110108

[31] Hirschman, E.C. (1980) Innovativeness, Novelty Seeking, and Consumer Creativity. Journal of Consumer Research, 7, 283-295. https://doi.org/10.1086/208816

[32] Price, L. and Ridgway, N.M. (1983) Development of a Scale to Measure Use Innovativeness. Advances in Consumer Research, 10, 679-684.

[33] Hoelter, J.W. (1983) The Analysis of Covariance Structures: Goodness-of-Fit Indices. Sociological Methods \& Research, 11, 325-344. https://doi.org/10.1177/0049124183011003003

[34] Hoe, S.L. (2008) Issues and Procedures in Adopting Structural Equation Modeling Technique. Journal of Applied Quantitative Methods, 3, 76-83.

[35] O'Cass, A. (2004) Fashion Clothing Consumption: Antecedents and Consequences of Fashion Clothing Involvement. European Journal of Marketing, 38, 869-882. https://doi.org/10.1108/03090560410539294

[36] O'Cass, A. and Choy, E. (2008) Studying Chinese Generation Y Consumers' Involvement in Fashion Clothing and Perceived Brand Status. Journal of Product \& Brand Management, 17, 341-352. https://doi.org/10.1108/10610420810896095

[37] Yang, H.S. and Lee, Y.R. (2009) Adolescents Fashion Innovativeness and Evaluation of Korean Image Fashion Products. Journal of the Korean Society of Clothing and Textiles, 33, 666-677. https://doi.org/10.5850/JKSCT.2009.33.4.666

[38] Girardi, A., Soutar, G.N. and Ward, S. (2005) The Validation of a Use Innovativeness Scale. European Journal of Innovation Management, 8, 471-481. https://doi.org/10.1108/14601060510627830

[39] Nunnally, J.C. and Bernstein, I.H. (1994) Psychological Theory. MacGraw-Hill, New York.

[40] Hair, J.F., Black, W.C., Babin, B.J., Anderson, R.E. and Tatham, R.L. (2010) Multivariate Data Analysis. 6th Edition, Pearson Prentice Hall, Upper Saddle River.

[41] Browne, M.W. and Cudeck, R. (1992) Alternative Ways of Assessing Model Fit. Sociological Methods and Research, 21, 230-258. https://doi.org/10.1177/0049124192021002005

[42] Bagozzi, R.P. and Yi, Y. (1988) On the Evaluation of Structural Equation Models. Journal of the Academy of Marketing Science, 16, 74-94. https://doi.org/10.1007/BF02723327

[43] Fornell and Larcker, D.F. (1981) Structural Equation Models with Unobservable Variables and Measurement Errors: Algebra and Statistics. Journal of Marketing Research, 18, 382-388. https://doi.org/10.2307/3150980

[44] Baron, R.M. and Kenny, D.A. (1986) The Moderator-Mediator Variable Distinction in Social Psychological Research: Conceptual, Strategic and Statistical Considerations. Journal of Personality and Social Psychology, 51, 1173-1182. https://doi.org/10.1037/0022-3514.51.6.1173

[45] Steenkamp, J.B.E., Hofstede, F.T. and Wedel, M. (1999) A Cross-National Investigation into the Individual and National Cultural Antecedents of Consumer Innovativeness. The Journal of Marketing, 63, 55-69. https://doi.org/10.2307/1251945 
[46] Goldsmith, R. and Reinecke Flynn, L. (1992) Identifying Innovators in Consumer Product Markets. European Journal of Marketing, 26, 42-55.

https://doi.org/10.1108/03090569210022498 